\title{
PEMAHAMAN ANAK TERHADAP AGAMA \\ MENURUT PERSEPSI GURU PAUD \\ (MAHASISWA NON-REGULER PIAUD UIN ANTASARI)
}

\author{
Anwar Zain \\ Pendidikan Islam Anak Usia Dini (PIAUD) \\ Fakultas Tarbiyah dan Keguruan \\ UIN Antasari Banjarmasin
}

\begin{abstract}
ABSTRAK
Dimensi agama sebenarnya sudah ada pada anak sejak ia masih kecil bahkan ketika masih didalam perut ibunya, karena dimensi agama merupakan naluri jiwa yang ada dalam setiap fithrah (potensi) anak. Anak usia dini merupakan dunia bermainnya anak, anak pada usia ini selalu ingin bergerak melakukan hal-hal yang menyenangkan. Tetapi walaupun demikian, anak pada usia ini juga mempunyai naluri agama dan pemahaman agama, karena kegiatan ibadah agama dan nasehat-nasehat keagamaan akan dijumpainya baik di rumah, di lingkungan dan di sekolah.

Tujuan penenlitian ini untuk mengetahui bagaimana pemahaman anak usia dini terhadap agama melalui persepsi guru-guru PAUD, yanga mana guru-guru ini juga sebagai mahasiswa non-reguler Jurusan PIAUD Fakultas Tarbiyah dan Keguruan UIN Antasari Banjarmasin. Metode penelitian adalah deskriptif-kualitatif dengan pendekatan penelitian lapangan (feil fesarch), dan subjeknya adalah mahasiswa non-reguler PIAUD yanag dalam keseharian mereka mengajar sebagai Guru dan Kepala Sekolah di RA (Raudhatul Athfal) yang berjumlah 43 ahasiswa.

Hasil penelitian ini menunjukkan bahwa pemahaman anak terhadap agama terbagi menjadi 5 dimensi; 1) dimensi pahala dan dosa, 2) dimensi syurga dan neraka, 3) dimensi ibadah dzohir (nampak) dan 4) agama sebagai aturan dimensi, 5) agama sebagai identias.
\end{abstract}

Kata Kunci : Peahaman Anak, Agama, Persepsi Guru 


\section{PENDAHULUAN}

Agama merupakan fitrah (potensi) yang ada dalam setiap diri manusia, dengan demikian setiap manusia secara naluri mempunyai perasaan keinginan dan keperluan dengan agama. Begitu juga anak yang lahir dari kedua orang tuanya ia membawa fitrah suci dalam dirinya tergantung kepada orang tuanya dalam menanamkan nilai-nilai agama tersebut. Hal ini sebagaimana yang telah disabdakan oleh Nabi Muhammad SAW.

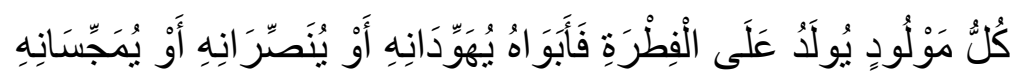

"Setiap anak dilahirkan dalam keadaan fithrah.Kemudian kedua orang tuanyalah yang akan menjadikan anak itu menjadi Yahudi, Nashrani atau Majusi” (Hadits shohih bukhari no. 1296).

Berdasarkan hadits di atas, bahwa fitrah beragama tidak hanya muncul pada saat manusia itu berusia dewasa, tetapi fitrah beragama manusia itu sudah ada terpatri dalam diri manusia sejak kecil (anak-anak). Hal ini bisa terlihat dari sikap dan perilaku anak-anak yang suka meniru orang tuanya ketika beribadah.Secara tidak langsung anak itu mempunyai rasa keinginan dengan perilaku ibadah yang dilakukan orang tuanya tersebut.Anak yang paling suka dan pandai meniru perilaku orang tua atau orang dewasa adalah anak pada usia dini.

Anak usia dini adalah kelompok anak yang berada dalam proses pertumbuhan dan perkembangan yang bersifat unik, dalam arti memiliki pola pertumbuhan dan perkembangan (koordinasi motorik halus dan kasar), intelegensi (daya pikir, daya cipta, kecerdasan emosi, dan kecerdasan spiritual), sosial emosional (sikap dan perilaku serta agama), bahasa dan komunikasi yang khusus sesuai dengan tingkat pertumbuhan dan perkembangan anak. Berdasarkan keunikan dalam pertumbuhan dan perkembangannya, anak usia dini terbagi dalam empat tahapan, yaitu (a) masa bayi lahir sampai 12 bulan, (b) masa toddler (batita) usia 1-3 tahun, (c) masa prasekolah usia 3-6 tahun, (d) masa kelas awal SD 6-8 tahun. Pertumbuhan dan perkembangan anak usia dini perlu diarahkan pada peletakan dasar-dasar yang tepat bagi pertumbuhan dan perkembangan manusia seutuhnya, yaitu pertumbuhan dan perkembangan fisik, daya pikir, daya 
cipta, sosial emosional, bahasa dan komunikasi yang seimbang sebagai dasar pembentukan pribadi yang utuh (Hartoyo, 2004:3).

Anak usia dini merupakan individu yang sedang mengalami proses pertumbuhan dan perkembangan yang sangat pesat, bahkan dikatakan sebagai lompatan perkembangan. Anak usia dini memiliki rentang usia yang sangat berharga dibanding usia-usia selanjutnya karena perkembangan kecerdasannya sangat luar biasa. Usia tersebut merupakan fase kehidupan yang unik, dan berada pada masa proses perubahan berupa pertumbuhan, perkembangan, pematangan dan penyempurnaan, baik pada aspek jasmani maupun rohaninya yang berlangsung seumur hidup, bertahap, dan berkesinambungan (Mulyasa, 2012: 16).

Pendidikan anak usia dini difokuskan untuk mengembangkan seluruh aspek potensi anak. Dengan demikian, anak harus menerima stimulus semua aspek perkembangan, meliputi: kognitif, bahasa, sosial-emosional, fisik-motorik seni dan moral-agama (Maemunah, 2013: 1). Aspek pengembangan pada anak usia dini yang paling strategis dalam kejiwaan anak adalah aspek moral-agama pada diri anak, karena anak sejak dalam kandungan sampai lahir kedunia, anak sudah dikenalkan orang tuanya dengan nilai-nilai agama.

Mendidik anak usia dini dengan pendidikan agama tentu kita harus mengetahui hakikat dan tujannya, agar dalam mendidik anak bisa memahami dan mengerti inti dan tujuan pendidikan tersebut. Menurut Mursid (2015:88) bahwa "hakikat pendidikan agama adalah usaha orang tua dewasa secara sadar untuk membimbing dan mengarahkan kepribadian serta kemampuan dasar anak didik, baik dalam bentuk pendidikan agama, formal dan non formal”. Sedangkan Syukir (2010: 157) menyatakan bahwa "hakikat dari pendidikan agama adalah penanaman moral beragama pada anak, sedangkan pengajaran adalah memberikan pengetahuan agama pada anak didik". Pendidikan agama pada dasarnya adalah membina (melestarikan) fitrah agama pada anak yang dibawa sejak lahir,agar tidak luntur menjadi atheis. Oleh karena itu yang harus diperhatikan adalah membiasakan anak untuk melaksanakan syari'at agama dan menjauhkan larangan-Nya. 
Pendidikan agama akan berhasil secara efektif apabila ditanamkan sejak usia dini, karena Usia dini merupakan usia yang paling penting karena awal bagi pertumbuhan dan perkembangan anak yang membawa ke arah kehidupan mereka selanjutnya. Dengan perhatian dan kesadaran terhadap pendidikan anak sejak usia dini akan memberikan dampak yang positif. Hal ini dikuatkan dengan pendapat Montessori bahwa saat usia dini anak mengalami masa peka dimana anak sangat mudah menerima stimulasi dari luar dirinya (Rahman, 2002:5).

Pendidikan agama di PAUD merupakan pendidikan yang sifatnya pengenalan agama, karena anak usia dini mempelajari agama dengan dasar mengenal ajaran agamanya dulu secara umum dari hal yang konkret. Adapun menurut Jalaluddin (2003: 70) bahwa pengenalan ajaran agama sejak dini sangat berpengaruh dalam membentuk kesadaran dan pengalaman agama pada diri anak. Adanya kesadaran dan pengalaman agama pada anak akan membentuk budi pekerti, perasaan, cita rasa dan kepribadian positif yang sangat penting bagi kehidupan anak selanjutnya baik secara personal maupun interpersonal. Nilai agama sebagai standar perilaku berfungsi untuk mengarahkan, mengendalikan, dan menentukan perilaku seseorang.

Pengembangan agama sejak usia dini memerlukan dorongan dan rangsangan sebagaimana pohon memerlukan air dan pupuk. Minat dan cita-cita anak perlu ditumbuhkembangkan ke arah yang lebih baik dan terpuji melalui pendidikan dan keteladanan. Oleh karena itu, dalam pendidikan agama para pendidik dituntut untuk menjalankan kewajiban-kewajiban agama. Jika para pendidik menjadikan dirinya sebagai teladan dalam masalah ini, maka hal ini akan berdampak efektif bagi kepatuhan anak-anak dalam menjalankan kewajiban agama mereka.

Agama merupakan hal yang abstrak bagi dunia anak, karena kebanyakan dari dimensi dari agama tidak bisa terlihat atau tidak bisa diwakilkan dengan manisfestasi suata alat peraga, misalnya; iman kepada Allah, malaikat, syurga dan neraka, dosa dan pahala dan lain sebagainya.Oleh karena itu, seorang guru harus mempunyai kualitas kompetensi dalam memahamkan kognitif anak tentang agama dengan mudah dan sederhana. Apabila kita meninjau dari struktur isi 
kurikulum, maka pada aspek pengembangan agama maka dimuatkan dala KI (Kompetensi Inti) 1, yang mana kalau KI 1 itu dalam praktik pembelajaran ia tidak bisa ditargetkan menjadi tujuan pembelajaran, tapi KI 1 aspek agama itu berkembang sebagaimana tingkat perkembangan anak yang tidak bisa disamakan antara satu anak dengan yang lain. Oleh sabab itu, para guru penting dalam menilai tentang pemahaman anak tentang agama secara pengamatan berkelanjutan sehari-hari, karena aspek agama ini tidak bias dilakukan Tes dalam mengetahui tercapainya indikator agama, tapi guru hanya perlu melihat secara perilaku anak yang menggambarkan tentang pemahamannya terhadap agama. 


\section{PEMBAHASAN}

\section{A. Konsep Agama}

\section{Hakikat Agama}

Dalam kamus umum bahasa Indonesia, agama berarti segenap kepercayaan kepada Tuhan, Dewa dan sebagainya, serta dengan ajaran kebaktian dan kewajiban-kewajiban yang bertalian dengan kepercayaan itu (Poerwadarminta, 1982: 18). Agama dari sudut bahasa (etimologi) berarti peraturan-peraturan tradisional, ajaran-ajaran, kumpulan-kumpulan hukum yang turun temurun dan ditentukan oleh adat kebiasaan. Agama asalnya terdiri dari dua suku kata, yaitu "a" berarti tidak dan "gama" berarti kacau. Jadi, agama mempunyai arti tidak kacau. Arti ini dapat dipahami dengan melihat hasil yang diberikan oleh peraturan- peraturan agama kepada moral atau materiil pemeluknya, seperti yang diakui oleh orang yang mempunyai pengetahuan, (Abdullah : $2004: 2$ )

Agama semakna juga dengan kata ad-din (bahasa Arab) yang berarti cara, adat kebiasaan, peraturan, undang-undang, taat dan patuh, mengesakan Tuhan, pembalasan, perhitungan, hari kiamat dan nasihat ( Ali : 2007 : 25). Dalam bahasa Latin dari kata religi, dan dalam bahasa Inggeris dari kata religion. Religion dalam bahasa inggris (dinun) dalam bahasa Arab memiliki arti sebagai berikut:

a. Organisasi masyarakat yang menyusun pelaksanaan segolongan manusia yang periodik, pelaksanaan ibadah, memiliki kepercayaan, yaitu kesempurnaan zat yang mutlak, mempercayai hubungan manusia dengan kekuatan rohani yang leibih mulia dari pada ia sendiri. Rohani itu terdapat pada seluruh alam ini, baik dipandang esa, yaitu Tuhan atau dipandang berbilang-bilang.

b. Keadaan tertentu pada seseorang, terdiri dari perasaan halus dan kepercayaan, termasuk pekerjaan biasa yang digantungkan dengan Allah SWT.

c. Penghormatan dengan khusuk terhadap sesuatu perundang-undangan atau adat istiadat dan perasaan. (Abdullah, 2004: 3) 
Menurut Durkheim, agama ialah sistem kepercayaan dan praktik yangg dipersatukan yangg berkaitan dengan hal-hal yangg kudus. Bagi Spencer, agama ialah kepercayaan terhadap sesuatu yangg Maha Mutlak. Sementara Dewey, menyatakan bahwa agama ialah pencarian manusia terhadap cita-cita umum dan abadi meskipun dihadapkan pada tantangan yangg dapatt mengancam jiwanya; agama ialah pengenalan manusia terhadap kekuatan gaib yangg hebat. Dengan demikian, mengikuti pendapatt Smith, tidak berlebihan jika kita katakan bahwa hingga saaat ini belum ada definisi agama yangg benar dan dapatt diterima secara universal (Abdulrahim. 1996: 26-35).

Menurut Harun Nasution yang dikutip oleh Nata (2011: 14), memberikan definisi agama sebagai berikut.

a. Pengakuan terhadap adanya hubungan manusia dengan kekuatan gaib yang harus di dipatuhi.

b. Pengakuan terhadap adanya kekuatan gaib yang menguasai manusia

c. Mengikatkan diri pada suatu bentuk hidup yang mangandung pengakuan pada suatu sumber yang berada di luar diri manusia yang mempengaruhi perbuatan-perbuatan manusia.

d. Kepercayaan pada suatu kekuatan gaib yang menimbulkan cara hidup tertentu.

e. Suatu sistem tingkah laku (code of conduct) yang berasal dari kekuatan gaib.

f. Pengakuan terhadap adanya kewajiban-kewajiban yang diyakini bersumber pada suatu kekuatan gaib.

g. Pemujaan terhadap kekuatan gaib yang timbul dari perasaan lemah dan perasaan takut terhadap kekuatan misterius yang terdapat dalam alam sekitar manusia.

h. Ajaran yang diwahyukan Tuhan kepada manusia melalui seorang rasul. 
Dari beberapa definisi tersebut di atas, ada empat unsur yang menjadi karakteristik agama sebagai beirkut (Nata, 2011: 15) : Pertama, unsur kepercayaan terhadap kekuatan gaib. Kekuatan gaib tersebut dapat mengambil bentuk yang bermacam-macam. Dalam agama primitif kekuatan gaib tersebut dapat mengambil bentuk benda-benda yang memiliki kekuatan misterius (sakti), ruh atau jiwa yang terdapat pada benda- benda yang memiliki kekuatan misterius; dewa-dewa dan Tuhan. Kepercayaan pada adanya Tuhan adalah dasar yang utama sekali dalam paham keagamaan. Tiap-tiap agama kecuali Budhisme (Budha) yang asli dan beberapa agama lain berdasar atas kepercayaan pada sesuatu kekuatan gaib dan cara hidup tiap-tiap manusia yang percaya pada agama di dunia ini amat rapat hubungannya dengan kepercayaan tersebut.

Kedua, unsur kepercayaan bahwa kebahagiaan dan kesejahteraan hidup di dunia ini dan di akhirat nanti tergantung pada adanya hubungan yang baik itu, kesejahteraan dan kebahagiaan yang dicari akan hilang pula. Hubungan baik ini selanjutnya diwujudkan dalam bentuk peribadatan, selalu mengingat-Nya, melaksanakan segala perintah-Nya dan menjauhi larangan-Nya

Ketiga, unsur respon yang bersifat emosional dari manusia, respon tersebut dapat mengambil bentuk rasa takut, seperti yang terdapat pada agama primitif, atau perasaan cinta seperti yang terdapat pada agama-agama monoteisme. Selanjutnya respon tersebut dapat pula mengambil bentuk penyembahan seperti yang terdapat pada agama-agama monoteisme dan pada akhirnya respon tersebut mengambil bentuk dan cara hidup tertentu bagi masyarakat ang bersangkutan.

Keempat, unsur paham adanya yang kudus (sacred) dan suci, dalam bentuk kekuatan gaib, dalam bentuk kitab suci yang mengandung ajaranajaran agama yang bersangkutan, tempat-tempat tertentu, peralatan untuk menyelenggarakan upacara, dan sebagainya.

Berdasarkan uraian tersebut dapat disimpulkan bahwa agama adalah ajaran yang berasal dari Tuhan atau hasil renungan manusia yang terkandung dalam kitab suci yang turun temurun diwariskan oleh suatu generasi ke generasi dengan 
tujuan untuk memberi tuntunan dan pedoman hidup bagi manusia agar mencapai kebahagiaan di dunia dan akhirat, yang di dalamnya mencakup unsur kepercayaan kepada kekuatan gaib yang selanjutnya menimbulkan respon emosional dan keyakinan bahwa kebahagiaan hidup tersebut tergantung pada adanya hubungan yang baik dengan kekuatan gaib tersebut.

Adapun fungsi agama menurut Rasyid (1983: 19) sebagai berikut.

a. Sumber pedoman hidup bagi individu maupun kelompok

b. Mengatur tata cara hubungan manusia dengan Tuhan dan manusia dengan manusia

c. Merupakan tuntutan tentang prinsip benar atau salah

d. Pedoman mengungkapkan rasa kebersamaan

e. Pedoman perasaan keyakinan

f. Pedoman keberadaan

g. Pengungkapan estetika (keindahan)

h. Pedoman rekreasi dan hiburan

i. Memberikan identitas kepada manusia sebagai umat dariii suatu agama

\section{B. Konsep Pengembangan Agama Anak}

1. Pengertian Pengembangan Agama Anak Usia Dini

Perkembangan berasal dari kata dasar "kembang" mendapat awalan "pe" dan akhiran "an". Artinya perbuatan yang menjadikan tambah sempurna (tentang pribadi, pikiran, dan pengetahuan) (KBBI, 1994: 473).

Kata keagamaan berasal dari kata dasar Agama dan mendapat awalan "ke" dan akhiran "an" yang artinya adalah kepercayaan kepada Tuhan; hal-hal gaib yang memiliki kekuatan besar; akidah (Kamus Ilmiah Populer, 2006: 9). Menurut Nasution, Agama mengandung arti ikatan yang harus dipegang dan di patuhi manusia. Ikatan dimaksud berasal dari suatu kekuatan yang lebih dari manusia sebagai kekuatan yang gaib yang tak dapat ditangkap dengan pancaindra, namun mempunyai pengaruh yang besar sekali terhadap kehidupan manusia sehari-hari (Rahmat, 2002: 22). Keagamaan merupakan segala sesuatu yang berhubungan 
dengan agama. Artinya segala hal baik berupa sikap, ritual maupun kepercayaan yang bersifat agama masuk kedalam keagamaan.

Jadi, yang dimaksud dengan pengembangan agama pada anak usia dini adalah terjadinya proses penanaman nilai-nilai kegamaan yang terinternalisasi dalam diri anak, kemudian terwujud dalam perilaku baik sehari-harinya sesuai dengan tahapan perkembangan anak dalam memahami dan mengerjakan nilai-nilai agama tersebut.

2. Perkembangan Keagamaan Anak

Perkembangan agama pada anak-anak pada usia anak memiliki kerakteristik tersendiri. Menurut penelitian ernest harms perkembangan agama pada anak-anak melalui beberapa 3 fase atau tingkatan. (Jalaluddin, 2003: 66).

\section{a. The Fairy Tale Stage ( Tingkat Dongeng )}

Tingkatan ini dimulai pada anak usia 3-6 tahun. Pada tingkatan ini konsep mengenai Tuhan lebih banyak dipengaruhi oleh fantasi dan emosi. Pada tingkat perkembangan ini anak menghayati konsep ke- Tuhanan sesuai dengan tingkat perkembangan inteleknya. Kehidupan masa ini masih banyak dipengaruhi kehidupan fantasi hingga dalam menanggapi agamapun anak masih menggunakan konsep fantatis yang diliputi oleh dongeng-dongeng yang kurang masuk akal.

b. The Realistic Stage (Tingkat Kenyataan)

Tingkat ini dimulai sejak 7-12 tahun. Pada fase ini anak mampu memahami konsep ketuhanan secara relistik dan kongkrit. Pada masa ini ide keagamaan pada anak didasarkan atas dorongan emosional, hingga mereka dapat melahirkan konsep Tuhan yang formalis.

c. The Individual Stage (Tingkat Individu)

Tingkat ini terjadi pada usia remaja. Situasi jiwa yang mendukung perkembangan rasa keTuhanan pada usia ini adalah kemampuannya untuk berfikir abstrak dan kesensitifan emosinya. Pemahaman keTuhanan padan remaja dapat ditekankan pada makna dan keberadaan Tuhan bagi kehidupan manusia. 
3. Sifat-sifat keagamaan pada anak-anak

Clark merumuskan delapan karakteristik religiusitas (keagamaan) pada anak, yaitu.

a. Ideas Accepted On Authority, yaitu semua pengetahuan yang dimiliki anak datang dari luar dirinya terutama dari orangtuanya. Semenjak lahir anak sudah terbentuk untuk mau menerima dan terbiasa untuk mentaati apa yang disampaikan orang tua, karena dengan demikian akan menimbulkan rasa senang dan rasa aman dalam dirinya. Maka nilai-nilai agama yang diberikan oleh orangtua atau orangtua pengganti dengan sendirinya akan terekam dan melekat pada anak. dalam hal ini maka orangtua mempunyai otoritas yang kuat untuk membentuk religiusitas anak

b. Unreflective, yaitu anak menerima konsep keagamaan berdasarkan otoritas, maka jarang terdapat anak yang melakukan perenungan (refleksi) terhadap konsep keagamaan yang diterima. Pengetahuan yang masuk pada usia awal dianggap sebagai suatu yang menyenangkan, terutama yang dikemas dalam bentuk cerita.oleh karena itu konsep tentang nilai-nilai keagaman dapat sebanyak mungkin diberikan pada usia anak dan sebaiknya disampaikan dalam bentuk cerita.

c. Egocentric, yaitu mulai usia sekitar satu tahun pada anak terkembang kesadaran tentang keberadaan diri tumbuh egosentrisme, dimana anak melihat lingkungannya dengan berpusat pada kepentingan dirinya. Maka pemahaman religiusitas anak juga didasarkan pada kepentingan diri tentang masalah keagamaan. Oleh karena itu pendidikan agama sebaiknya lebih dikaitkan pada kepentingan anak, misalnya ketaatan ibadah dikaitkan dengan kasih sayang Tuhan terhadap dirinya.

d. Anthropomorphic, yaitu sifat anak yang mengkaitkan keadaan suatu yang abstrak dengan manusia. Dalm hal ke Tuhanan maka anak mengkaitkan sifat-sifat Tuhan dengan sifat manusia. Hal ini terjadi 
karena lingkungan anak yang pertama adalah manusia sehingga manusialah sebagai ukuran bagi suatu yang lain. Oleh karena itu dalam pengenalan sifat-sifat Tuhan kepada anak sebaiknya ditekankan tentang perbedaan sifat antara manusia dan Tuhan.

e. Verbalized And Ritualistic, yaitu perilaku keagamaan pada anak, baik yang menyangkut ibadah maupun moral, baru bersifat lahiriyah, verbal dan ritual, tanpa keinginan untuk dilakukan dan diajarkan oleh orang dewasa. Akan tetapi bila perilaku keagamaan itu dilakukan dan diajarkan oleh orang dewasa, dan bila perilaku keagamaan itu dilakukan secara terus menerus dan penuh minat akan membentuk suatu rutinitas perilaku yang sulit untuk ditinggalkan. Pada waktu anak memasuki usia remaja baru akan muncul keinginan untuk mengetahui makna dan fungsi dari apa yang selama ini dilakukan. Oleh karena itu pendidikan agama perlu menekankan pembiasaan perilaku dan pembentukan minat untuk melakukan perilaku keagamaan.

f. Imitative, yaitu sifat dasar anak dalam melakukan perilaku seharihari adalah menirukan apa yang terserap dari lingkungannya. Demikian juga dalam perilaku keagamaan. Anak mampu memiliki perilaku keagamaan karena menyerap secara terus menerus perilaku keagamaan dari orang-orang terdekatnya, terutama orangtua dan anggota keluarga yang lain. Ditambah dengan daya sugesti dan sikap positif orangtua terhadap perilaku yang telah dilakukan akan memperkuat aktivitas anak dalam berperilaku keagamaan. Oleh karena itu menempatkan anak dalam lingkungan beragama menjadi prasarat terbukanya religiusitas anak.

g. Spontaneous In Some Respeck, yaitu berbeda dengan sifat imitative anak dalam melakukan perilaku keagamaan, kadang-kadang muncul perhatian secara spontan terhadap masalah keagamaan yang abstrak. Misalnya tentang surga, neraka, tempat Tuhan berada, atau yang lainnya. Keadaan tersebut perlu mendapat perhatian dari 
orangtua atau pendidik agama, karena dari pertanyaan spontan itulah sebenarnya permulaan munculnya tipe primer pengalaman religiusitas yang dapat berkembang.

h. Wondering, yaitu ini bukan jenis ketakjuban yang mendorong munculnya pemikiran kreatif dalam arti intelektual, tetapi sejenis takjub yang menimbulkan rasa gembira dan heran terhadap dunia baru yang terbuka didepanya. Suasana ketakjuban dan kegembiraan ini masih dapat terbawa pada usia dewasa, ketika seseorang memproyeksikan ide-idenya mengenai Tuhan dan ciptaan-Nya serta menemukan rasa ketakjuban disana. Pada anak takjub ini dapat menimbulkan ketertarikan pada cerita-cerita keagamaan yang bersifat fantastis, misalnya peristiwa mukjizat pada sejarah Nabi-nabi, serta cerita kehebatan para sahabat dan pahlawan islam. (Otib Satibi, 2009: $8.15)$.

4. Munculnya jiwa keagamaan anak

Ada beberapa teori timbulnya keagamaan anak, yakni:

a. Rasa ketergantungan

Manusia dilahirkan kedunia ini memiliki empat kebutuhan, yakni keinginan untuk perlindungan (security), keinginan akan pengalamn baru (new experience), keinginan untuk dapat tanggapan (response), keinginan untuk dikenal (recognition). Berdasarkan kenyataan dan kerjasama dari keempat keinginan itu, maka bayi sejak dilahirkan hidup dalam ketergantungan. Melalui pengalaman-pengalaman yang diterimanya dari lingkungan itu kemudian terbentuklah rasa keagaman pada diri anak.

b. Instink keagamaan

Bayi yang dilahirkan sudah memiliki beberapa instink. Diantaranya instink kagamaan. Belum terlihatnya tindak keagamaan pada diri anak karena beberapa fungsi kejiwaan yang menopang kematangan berfungsinya instink itu belum sempurna. Dengan demikian pendidikan agama perlu diperkenalkan kepada anak jauh sebelum usia 
7 tahun. Artinya, jauh sebelum usia tersebut, nilai-nilai keagamaan perlu ditanamkan kepada anak sejak usia dini. Nilai keagamaan itu sendiri bisa berarti perbuatan yang berhubungan antara manusia dengan Tuhan atau hubungan antar sesama manusia (Mansur, 2007: 47-48).

\section{Aspek Pengembangan Agama pada AUD}

Istilah kata pendidikan atau pembelajaran pada PAUD mengalami penggunaan kata yang berbeda dengan tingkat sekolah lainnya seperti di SD/SMP/SMA, di PAUD kata pendidikan atau pembelajaran lebih menggunakan istilah kata "Pengembangan". Karena anak pada PAUD itu dipandang sebagai seseorang yang mempunyai bekal kemampuan potensi, tugas pendidik/guru hanya lebih kepada mengembangkan kemampuan potensi yang ada pada diri anak tersebut, meliputi: moral-agama, sosialemosional, kognitif, bahasa, fisik-motorik dan seni. Hal ini senada dengan penjelasan tentang struktur kurikulum PAUD pada Permendikbu No. 146 Tahun 2014, bahwa dalam istilah pendidikan atau pembelajaran pada PAUD itu menggunakan istilah pengembangan, yaitu kurikulum PAUD memuat program-program pengembangan yang mencakup: nilai agama dan moral, fisik-motorik, kognitif, bahasa, sosial-emosional dan seni. Oleh karena itu, dalam PAUD istilah kata pendidikan menggunakan kata pengembangan.

Pendidikan atau pengembangan keagamaan anak usia dini merupakan hal yang sangat penting dilakukan pada PAUD, karena aspek keagamaan pada anak sangat membantu dalam mengembangkan potensi naluri agama yang ada pada diri anak, anak yang ditanamkan agama sejak dini akan menjadi fondasi kuat dalam hati kepercayaannya dan sikap perbuatan lahirnya agar menjadi baik. Pendidikan atau pengembangan keagamaan pada anak usia dini berbeda dengan pendidikan keagamaan pada anak dewasa, pengembangan keagamaan pada anak usia dini lebih kepada mengaitkan dan mengasosiasikan segala apa yang dilihatnya dan kejadian pengalamannya kepada Tuhan yang maha Esa serta 
melaksanakan ibadah agama dengan tuntunan orang tua dan pendidik/guru dengan pembiasaan dan teladan.

Pendidikan atau pengembangan keagaamaan pada anak usia dini tidak akan terlepas dari kurikulum yang berlaku pada lembaga PAUD. Adapun kurikulum yang berlaku pada PAUD mengacu pada kurikulum 2013 yang tertuang dalam Permendikbud. No. 137 dan No. 146. 2014 tentang Kurikulum PAUD 2013. Di dalam kurikulum tersebut memuat Kometensi Inti (KI) dan Kompetensi Dasar ( KD) tentang aspek Spritual dan Sosial-Emosional yang berkaitan tentang pengembangan keagamaan, sebagaimana table di bawah ini.

Tabel 01 Kompetensi Inti dan Kompetensi Dasar

\begin{tabular}{|l|l|}
\hline KI & KD \\
\hline Spritual & 1.1.Mempercayai adanya Tuhan melalui ciptaan-Nya \\
\hline Kognitif & \begin{tabular}{l} 
3.1.Mengenal kegiatan beribadah sehari-hari \\
\hline Keterampilan
\end{tabular} \\
$\begin{array}{l}\text { 4.1.Melakukan kegiatan beribadah sehari-hari dengan tuntunan } \\
\text { orang dewasa }\end{array}$ \\
\hline Spritual & $\begin{array}{l}\text { 1.2. Menghargai diri sendiri, orang lain, dan lingkungan sekitar } \\
\text { sebagai rasa syukur kepada Tuhan }\end{array}$ \\
\hline Sosial-Emosional & $\begin{array}{l}\text { 2.10. Memiliki perilaku yang mencerminkan sikap menghargai } \\
\text { dan toleran kepada orang lain }\end{array}$ \\
\hline
\end{tabular}

Tabel 02. Indikator Pencapaian Perkembangan Anak

\begin{tabular}{|l|l|}
\hline Usia Anak & Indikator Pencapaian Perkembangan \\
\hline $4-5$ & $\begin{array}{l}\text { Mulai mengucapkan doa-doa pendek dan melakukan ibadah sesuai } \\
\text { dengan agama yang dianutnya }\end{array}$ \\
\hline $5-6$ & $\begin{array}{l}\text { Mengucapkan doa-doa pendek, melakukan ibadah sesuai } \\
\text { dengan agamanya (misal: doa sebelum memulai dan selesai } \\
\text { kegiatan). } \\
\text { Menyebutkan tempat ibadah agama lain }\end{array}$ \\
\hline
\end{tabular}

Berdasarkan tabel di atas, menunjukkan bahwa dasar acuan pendidikan keagamaan pada PAUD harus mengembangkan nilai-nilai kepercayaan kepada 
Tuhan, mengetahui dan melaksanakan ibadah agama secara tuntunan orang dewasa serta menumbuhkan rasa toleransi terhadap orang lain. Kemudian dalam Permendikbud No. 137 Tahun 2014 Pasal 10 menyatakan dengan jelas bahwa nilai agama dan moral meliputi: kemampuan mengenal nilai agama yang dianut, mengerjakan ibadah, berperilaku jujur, penolong, sopan, hormat, sportif, menjaga kebersihan diri dan lingkungan, mengetahui hari besar agama, menghormati, dan toleran terhadap agama orang lain.

D. Persepsi Mahasiswa terhadap Pemahaman Agama AUD

Dalam menggali tentang bagaimana persepsi mahasiswa terhadap pemahaman agama pada AUD ini menggunakan dengan pertanyaan wawancara terbuka. Adapun hasil penggalian data tentang persepsi persepsi mahasiswa terhadap pemahaman agama pada AUD dipaparkan sebagai berikut ini.

\begin{tabular}{|c|c|c|}
\hline No & Mahasiswa/Institusi Sekolah & Persepsi/Pemahaman \\
\hline 1 & $\begin{array}{l}\text { RA Nurul Islam } \\
\text { Banjarmasin Timur, Banjarmasin }\end{array}$ & $\begin{array}{l}\text { Anak mengenal agama meliputi tentang syurga-neraka } \\
\text { dan pahala-dosa, dikarenakan setiap hari guru } \\
\text { mengenalkan rukun iman, rukun islam, malaikat dan } \\
\text { tugas-tugasnya serta Asmaul Husna. }\end{array}$ \\
\hline 2 & $\begin{array}{l}\text { RA Darul Khair } \\
\text { Banjarmasin Barat, Banjarmasin }\end{array}$ & $\begin{array}{l}\text { Anak mengenal agama hanya sebatas meniru tentang } \\
\text { sholat, memahami siapa penciptanya, masuk syurga } \\
\text { bila berbuat baik dan masuk neraka bila berbuat jahat. }\end{array}$ \\
\hline 3 & $\begin{array}{l}\text { RA Al-Amin } \\
\text { Kertak Hanyar, Kab. Banjar }\end{array}$ & Anak mengenal agama hanya sebatas mana yang baik \\
\hline 4 & $\begin{array}{l}\text { RA NU Raudhatul jannah } \\
\text { Banjarmasin Selatan, Banjarmasin }\end{array}$ & $\begin{array}{l}\text { Anak mengenal agama hanya sebatas mengucapkan } \\
\text { (melafalkan) dan melaksanakan ibadah dengan } \\
\text { motivasi mendapat pahala di akherat dan masuk syurga }\end{array}$ \\
\hline 5 & $\begin{array}{l}\text { RA Al-Jawiyah } \\
\text { Banjarmasin Barat, Banjarmasin }\end{array}$ & $\begin{array}{l}\text { Anak mengenal agama sebatas Tuhan sebagai yang } \\
\text { menciptakan dengan berdo'a sehari-hari' }\end{array}$ \\
\hline 6 & $\begin{array}{l}\text { RA Al-Amanah } \\
\text { Banjarmasin Selatan, Banjarmasin }\end{array}$ & Anak mengenal agama sebatas pahala dan dosa \\
\hline
\end{tabular}




\begin{tabular}{|c|c|c|}
\hline 7 & $\begin{array}{l}\text { RA Datu Abulung } \\
\text { Banjarmasin Utara Banjarmasin }\end{array}$ & $\begin{array}{l}\text { Anak mengenal agama sebatas apa yang dilihat anak, } \\
\text { sperti sholat }\end{array}$ \\
\hline 8 & $\begin{array}{l}\text { RA Mulia Tanipah Aluh-Aluh } \\
\text { Kab. Banjar }\end{array}$ & $\begin{array}{l}\text { Anak mengenal agama sebatas mengenal mana yang } \\
\text { baik dan buruk }\end{array}$ \\
\hline 9 & $\begin{array}{l}\text { RA Mulia Tanipah } \\
\text { Aluh-Aluh, Kab. Banjar }\end{array}$ & $\begin{array}{l}\text { Anak mengenal agama hanya sebatas mana yang baik } \\
\text { dan buruk serta ibadah sholat }\end{array}$ \\
\hline 10 & $\begin{array}{l}\text { RA Mulia Tanipah } \\
\text { Aluh-Aluh, Kab. Banjar }\end{array}$ & $\begin{array}{l}\text { Anak mengenal agama sebatas paham bacan-bacaan } \\
\text { atau do'a-do'a ketika melakukan Sesutu, seperti mau } \\
\text { makan, mengucapkan dan menjawab salam dan do'a } \\
\text { sehari-hari lainnya. }\end{array}$ \\
\hline 11 & $\begin{array}{l}\text { RA Harapan Ibu } \\
\text { Aluh-Aluh, Kab. Banjar }\end{array}$ & enal agama sebatas syurga dan neraka \\
\hline 12 & $\begin{array}{l}\text { RA NU Ibnu Junaaidi } \\
\text { Banjarmasin Barat, Banjarmasin }\end{array}$ & $\begin{array}{l}\text { Anak mengenal agama sebatas apa kegiatan ibadah } \\
\text { yang dilihatnya maka akan ditirunya }\end{array}$ \\
\hline 13 & $\begin{array}{l}\text { TK-TPA Babus sa'adah } \\
\text { Banjarmasin Selatan, Banjarmasin }\end{array}$ & $\begin{array}{l}\text { Anak mengenal agama sebatas ikut-ikutan orang yang } \\
\text { disekitarnya, apabila disusruh atau dijelaskan tentang } \\
\text { agama, ia hanya melihat dan mendengar sejenak saja. }\end{array}$ \\
\hline 14 & $\begin{array}{l}\text { RA Khairul Jannah } \\
\text { Kertak Hanyar, Kab. Banjar }\end{array}$ & $\begin{array}{l}\text { Anak mengenal agama lebih kepada apa yang dilihat, } \\
\text { apabila anak sering melihat orang tunya membaca al- } \\
\text { Qur'an dan sholat, maka ia pun akan meniru dan } \\
\text { paham }\end{array}$ \\
\hline 15 & $\begin{array}{l}\text { RA Citra Islami } \\
\text { Banjarmasin Selatan Banjarmasin }\end{array}$ & $\begin{array}{l}\text { Anak mengenal agama apa saja yang dilihatnya dari } \\
\text { keluarga, lingkungan masyarakat dan sekolah }\end{array}$ \\
\hline 16 & $\begin{array}{l}\text { RA Al-Amin } \\
\text { Kertak Hanyar, Kab. Banjar }\end{array}$ & $\begin{array}{l}\text { Anak mengenal agama lebih kepada apa yang kita ia } \\
\text { lihat dan diajarkan kepada anak secara langsung }\end{array}$ \\
\hline 17 & $\begin{array}{l}\text { RA Harapan Ibu } \\
\text { Aluh-Aluh Kab. Banjar }\end{array}$ & $\begin{array}{l}\text { Anak mengenal agama sebagai aturan dan ikutan dari } \\
\text { orang tua dan guru di sekolah serta dapat membedakan } \\
\text { baik dan buruk }\end{array}$ \\
\hline 17 & $\begin{array}{l}\text { RA Babussalam } \\
\text { Banjarmasin Selatan, Banjarmasin }\end{array}$ & $\begin{array}{l}\text { Anak mengenal agama sebatas apa yang dilihat, } \\
\text { didengar dan dirasakannya }\end{array}$ \\
\hline
\end{tabular}




\begin{tabular}{|c|c|c|}
\hline 18 & $\begin{array}{l}\text { RA Mulia } \\
\text { Aluh-Aluh, Kab. Banjar }\end{array}$ & $\begin{array}{l}\text { Anak mengenal agama lebih kepada bila berberbuat } \\
\text { baik dapat pahala(syurga), dan bila berbuat jahat dapat } \\
\text { dosa (neraka) }\end{array}$ \\
\hline 19 & $\begin{array}{l}\text { PAUD Ar-Rahmah } \\
\text { Kertak hanyar, kab. Banjar }\end{array}$ & $\begin{array}{l}\text { Anak mengenal agama lebih kepada perbuatan baik } \\
\text { dan buruk, apa yang dilakukannya dengan kebaikan } \\
\text { maka itu mendapatkan pahala, bila ia mengganggu } \\
\text { temannya (berbuat nakal) maka ia mengganggap } \\
\text { berdosa }\end{array}$ \\
\hline 20 & $\begin{array}{l}\text { RA At-Taqwa } \\
\text { Banjarmasin Selatan, Banjarmasin }\end{array}$ & $\begin{array}{l}\text { Anak mengenal agama lebih kepada ikut-ikutan saja } \\
\text { dan kebiasaan }\end{array}$ \\
\hline 21 & $\begin{array}{l}\text { RA Ibnu Junaidi } \\
\text { Banjarmasin Barat, Banjarmasin }\end{array}$ & $\begin{array}{l}\text { Anak mengenal agama sebatas mencontohkan apa yang } \\
\text { dkilakukan oleh orang tuanya }\end{array}$ \\
\hline 22 & $\begin{array}{l}\text { RA Babussalam } \\
\text { Banjarmasin Selatan, Banjarmasin }\end{array}$ & $\begin{array}{l}\text { Anak mengenal agama hanya sebatas pemahaman } \\
\text { bahwa bila tidak bisa membaca al-Qur'an atau sholat } \\
\text { maka akan masuk syurga. }\end{array}$ \\
\hline 23 & $\begin{array}{l}\text { RA Babussalam } \\
\text { Banjarmasin Selatan, Banjarmasin }\end{array}$ & $\begin{array}{l}\text { Anak mengenal agama hanya sebatas takut akan masuk } \\
\text { neraka yang digambarkan dengan api neraka yang } \\
\text { sangat pana }\end{array}$ \\
\hline 24 & $\begin{array}{l}\text { RA Darul Khair } \\
\text { Banjarmasin Barat, Banjarmasin }\end{array}$ & $\begin{array}{l}\text { Anak mengenal agama dengan mengetahui adanya } \\
\text { Allah, syurga dan neraka berdasarkan penjelsan dan } \\
\text { kebiasaan dari orang disekitarnya }\end{array}$ \\
\hline 25 & $\begin{array}{l}\text { RA Islam Al-Irsyad Terpadu } \\
\text { Banjarmasin Utara Banjarmasin }\end{array}$ & $\begin{array}{l}\text { Anak mengenal agama dengan pemahaman apabila } \\
\text { banyak pahala akan masuk syurga, dan bila banyak } \\
\text { dosa akan masuk neraka. Banyak pahala bila ta'at atau } \\
\text { tidak nakal dan sebaliknya. Anak mengetahui siapa } \\
\text { Tuhan (dari ciptannya), Nabi dan kitab sucinya }\end{array}$ \\
\hline 26 & $\begin{array}{l}\text { RA Islam Bakti IV } \\
\text { Banjarmasin Utara, Banjarmasin }\end{array}$ & $\begin{array}{l}\text { Anak mengenal agama sebatas mengetahui Tuhan, } \\
\text { sholat, syurga dan neraka }\end{array}$ \\
\hline 27 & $\begin{array}{l}\text { RA al-Kautsar } \\
\text { Banjarmasin Selatan, Banjarmasin }\end{array}$ & $\begin{array}{l}\text { Anak mengenal agama dengan pemahaman bahwa } \\
\text { apabila berbuat baik akan mendapatkan pahala dan }\end{array}$ \\
\hline
\end{tabular}




\begin{tabular}{|c|c|c|}
\hline & & $\begin{array}{l}\text { masuk syurga, dan apabila berbuat tidak baik akan } \\
\text { mendapatkan dosa dan masuk neraka }\end{array}$ \\
\hline 28 & $\begin{array}{l}\text { PAUD Terpadu ar-Rahmah } \\
\text { Kertak Hanyar, Kab. Banjar }\end{array}$ & $\begin{array}{l}\text { Anak mengenal agama dengan pemahaman bahwa } \\
\text { secara umum tentang dosa dan pahala, apabila berbuat } \\
\text { baik akan mendapat pahala sehingga masuk syurga, } \\
\text { dan apabila berbuat tidak baik akan mendapat dosa } \\
\text { sehingga masuk neraka }\end{array}$ \\
\hline 29 & $\begin{array}{l}\text { RA Babussalam } \\
\text { Banjarmasin Selatan, Banjarmasin }\end{array}$ & $\begin{array}{l}\text { Anak mengenal agama sebatas dengan pemahaman } \\
\text { bahwa takut masuk neraka yang digambarkan dengan } \\
\text { api neraka yang begitu panas }\end{array}$ \\
\hline 30 & $\begin{array}{l}\text { RA Bina Anadrasa } \\
\text { Banjarmasin Selatan, Banjarmasin }\end{array}$ & $\begin{array}{l}\text { Anak mengenal agama sebatas pemahaman adanya } \\
\text { neraka dan syurga, apabila nakal mengganggu } \\
\text { temannya maka akan masuk neraka, dan bila tidak } \\
\text { nakal/usil dengan temannya maka akan masuk syurga }\end{array}$ \\
\hline 31 & $\begin{array}{l}\text { RA Islam bakti II } \\
\text { Banjarmasin Selatan, Banjarmasin }\end{array}$ & $\begin{array}{l}\text { Anak mengenal agama sebatas pemahaman tentang } \\
\text { pahala dan dosa, syurga dan neraka }\end{array}$ \\
\hline 32 & $\begin{array}{l}\text { RA Al-Kautsar } \\
\text { Banjarmasin Selatan, Banjarmasin }\end{array}$ & $\begin{array}{l}\text { Anak mengenal agama sebatas pemahaman tentang } \\
\text { dosa, misalnya apabila berbohong, tidak melaksanakan } \\
\text { sholat akan mendapatkan dosa }\end{array}$ \\
\hline 33 & $\begin{array}{l}\text { RA Al-Jawiyah } \\
\text { Banjarmasin Utara, Banjarmasin }\end{array}$ & $\begin{array}{l}\text { Anak mengenal agama sebatas pemahaman tentang } \\
\text { ibadah yang nampak dilihatnya yang apabila } \\
\text { dilaksankan mendapat pahala, bila tidak dikerjakan } \\
\text { ibadah maka akan berdosa }\end{array}$ \\
\hline 34 & $\begin{array}{l}\text { RA Khairul Jannah } \\
\text { Kertak Hanyar, Kab. Banjar }\end{array}$ & $\begin{array}{l}\text { Anak mengenal agama sebatas pemahaman bahwa } \\
\text { identitas nama agamanya adalah islam, kemudian } \\
\text { kegiatan ibadah kemesjid, dan apabila berbohong } \\
\text { lidahnya akan dipotong malaikat }\end{array}$ \\
\hline 35 & $\begin{array}{l}\text { RA Datu Abulung } \\
\text { Banjarmasin Utara, Banjarmasin }\end{array}$ & $\begin{array}{l}\text { Anak mengenal agama sebatas pemahaman bahwa } \\
\text { mengenal Allah melalui ciptaan langit, bumi, manusia, } \\
\text { binatang dan tumbuh-tumbuhan dan supaya anak bisa }\end{array}$ \\
\hline
\end{tabular}




\begin{tabular}{|l|l|l|}
\hline 36 & $\begin{array}{l}\text { RA Melati } \\
\text { Aluh-Aluh, Kab. Banjar }\end{array}$ & $\begin{array}{l}\text { Anak mengenal agama sebatas pemahaman bahwa } \\
\text { harus melaksanakan sholat, puasa, berbuat baik, dosa } \\
\text { dan pahala }\end{array}$ \\
\hline 37 & $\begin{array}{l}\text { RA Tarbiyatul Ulum } \\
\text { Banjarmasin Timur, Banjarmasin }\end{array}$ & $\begin{array}{l}\text { Anak mengenal agama sebatas pemahaman tentang } \\
\text { adanya syurga dan neraka serta mengahafal surah-surah } \\
\text { pendek }\end{array}$ \\
\hline 38 & $\begin{array}{l}\text { RA Islam Bakti VI } \\
\text { Banjarmasin Utara, Banjarmasin }\end{array}$ & $\begin{array}{l}\text { Anak mengenal agama sebatas tentang adanya pahala } \\
\text { dan dosa, rukun iman dan rukun islam }\end{array}$ \\
\hline 39 & $\begin{array}{l}\text { RA Babussalam } \\
\text { Banjarasin Selatan, Banjarmasin }\end{array}$ & $\begin{array}{l}\text { Anak mengenal agama sebatas mengenal nama-nama } \\
\text { agama saja, sperti di Indonesia ada beberapa agama }\end{array}$ \\
\hline 40 & $\begin{array}{l}\text { PAUD Al-Ikhwan } \\
\text { Alalak, Kab. Batola }\end{array}$ & $\begin{array}{l}\text { Anak mengenal agama sebatas mengenal dosa dan } \\
\text { pahala }\end{array}$ \\
\hline 41 & $\begin{array}{l}\text { RA Nur Iqro } \\
\text { Aluluh, Kab. Banjar }\end{array}$ & $\begin{array}{l}\text { Anak mengenal agama sebatas mengenal cara berbuat } \\
\text { baik }\end{array}$ \\
\hline 42 & $\begin{array}{l}\text { RA Darul Khair } \\
\text { Banjarmasin Barat, Banjarmasin } \\
\text { Anak mengenal agama sebatas mengenal ibadah, do'a }\end{array}$ \\
\hline
\end{tabular}

Berdasarkan pemaparan di atas, peahamana anak usia dini tentang agama dapat dirumuskan sebagai berikut.

1. Konsep Pahala dan Dosa

Anak memahami konsep pahala dan dosa berdasarkan perbuatan baik yang dilakukannya kepada orang lain, seperti menolong teman akan mendapat pahala , apabila berbuat nakal dengan teman akan mendapat dosa, apabila berbohong, tidak melaksankan sholat akan mendapatkan dosa. Peahaman anak mengenai konsep apahala juga berdasarkan pelaksanaan ibadah kepada Tuhan yang dilakukan anak, sperti anak akan mendapat paha apabila mengerjakan sholat, membaca do'a-do'a dan pelafalan surah-surah pendek.

Cara guru menanamkan konsep pahala dan dosa ini kepada anak dengan mengenalkan rukun Islam dan rukun Iman melalui bernyanyi dan penjelsanpenjelasan, di dalam butir rukun Iman ada menyangkut mengenai mengenalkan 
percaya pada Malaikat, pengenalan alaikat inisangat berdapakpada penguatan konseppahaladan dosa pada anak,karena anak akan terakam ingatannya bahwa apabila berbuat tidak baik seperti bohong dan menggangu orang lain aka ada malaikat yang akat mencatat perbuatannya tersebut yang akan berujung pada apakah banyak dosa atau pahala yang didapat anak.

\section{Konsep Syurga dan Neraka}

Konsep syurga dan neraka ini sebenarnya kelanjutan dari akibat ketika anak diperknalkan dengan konseppahaladan dosa, karena ujung dari tujuan pahala dan dosa adalah kelak akan bertempat di syurga atau di neraka. Oleh karena itu, konsep syurga dan neraka biasanya akan selalu muncul ketika para guru memberikan otivasiagaa kepadaanak, walaupun otivasi dari dapakpahala bisasajadi konretkan dengan halyang lain seperti diberikan akanan,kesehatan, tean yang baikdanlain sebagainya.

Konsep syurga dan neraka dipemahaman anak sangat banyak mendominasi dalam hasil wawancara dengan para guru, bahwa anak mengenal konsep dan syurga itu merupakan sebab-akibat dari perbuatan baik yang dilakukannnya pada sekarang ini. Apabila banyak perbuatan baik maka banyak pahala bila banyak pahala maka nanti akan masuk syurga, syurga itu tempat yang enak. Sedangkan neraka dipemahaman anak adalah sebuah tempat yang ada api bernyala-nyala yang sangat panas yang membakar penghuninya, siapakah penghuninya itu ? yaitu orang yang apabila sekarang ini banyak melakukan perbuatan tidak baik maka akan banyak dosa, bila banyak dosa maka masuk syurga. Sebagaimana ungkapan-ungkapan berikut ini;

a. Aanak melaksanakan ibadah dengan motivasi mendapat pahala di akherat dan masuk syurga.

b. Anak mengenal agama lebih kepada bila ber berbuat baik dapat pahala(syurga), dan bila berbuat jahat dapat dosa (neraka).

c. Anak mengenal agama hanya sebatas takut akan masuk neraka yang digambarkan dengan api neraka yang sangat panas

d. Apabila nak anakal mengganggu temannya maka akan masuk neraka, dan bila tidak nakal/usil dengan temannya maka akan masuk syurga 
Adapun anak mengenal syurga dan neraka berdasarkan penjelsan dan kebiasaan dari orang disekitarnya, baik orang tua maupun guru. Kebiasaan orang disekitar anak ini dalam mengenalkan syurga dan nerka itu lebih ditonjolkan nerkanya, karena ini senjata ampuh menurut orang disekitar dalam menakutnakuti si anak dengan "panasnya apai neraka". Padahal sebenarnya tidak mesti pendektan pengenalan syurga dan neraka itu hanya lebih ditonjolkan konsep neraka saja, apalgi untuk menjaga atau menegur anak ketika anak berbuat tidak baik. Seharusnya pendekatan konsep syurga juga harus lebih ditonjolkan, seperti pemahaman anak apabila tidak melakukan perbuatan yang tidak baik ini atau yang terlarang ini maka anak akan mendapatkan mainan nanti disyurga, mendapatkan apa saja yang anak sukai dengan menyandarkan sesuatu yang anak inginkan itu ada lengkap didalam syurga. Agar si anak dalam meninggalkan perbuatan yang tidak baik itu motivasi bukan takut, tapi motivasi untuk mendapatkan hadiah yang lebih baik di syurga nanti.

Konsep pahala-dosa dan syurga-nerka merupan Sesutu yang abstrak dengan menggunakan pendekatan fantasi dan rasa yang dibangun agar nak bisa membayangkan dan merasakan pahala akan membawa ke syurga, sedangkan dosa membawa ke neraka. Hal ini sejalan dengan pendapat Ernest Harms, bahwa anak usia usia 3-6 tahun konsep mengenai Tuhan lebih banyak dipengaruhi oleh fantasi dan emosi. Cara pengenalannya lebih ditekankan pada dongeng atau cerita-cerita (the fairy tale stage) dari orang tua dan guru. Kehidupan masa ini masih banyak dipengaruhi kehidupan fantasi hingga dalam menanggapi agamapun anak masih menggunakan konsep fantatis yang diliputi oleh dongeng-dongeng yang kurang masuk akal (Jalaluddin, 2002: 66).

\section{Konsep Perbuatan Ibadah Dzhoir}

Pemahaman anak terhadap agama hanya sebatas ibadah apa yang nampak (dzohir) dilihatnya dalam sehari-hari baik dirumah, di sekolah dan lingkungannya. Jadi, anak menganggap agama sebuah perbuatan ibadah yang dilakukan seseorang seperti; sholat, membaca al-Qur'an, membaca as-Maul Husna, membaca do'ado’a. 
Dengan demikian, anak mengenal agama hanya sebatas meniru atau ikutikutan yang dilakukan orang disekitarnya terhadap pelafalan (bacaan) dan gerakan/peragaan tata cara ibadah tersebut seperti sholat dan ibadah lainnya. Apabila anak sering melihat orang tunya, maka ia pun akan meniru dan paham Anak juga sebatas paham bacan-bacaan atau do'a-do'a ketika melakukan sesutu, seperti mau makan, mengucapkan dan menjawab salam dan do'a sehari-hari lainnya.

Anak dalam konsep ini mempunyai potensi meniru ibadah agama yang dilakukan oleh orang disekitarnya, hal ini senada dengan pendapat Calrk bahwa karakteistik keagamaan anak bersifat imitatif, yaitu sifat dasar anak dalam melakukan perilaku sehari-hari adalah menirukan apa yang terserap dari lingkungannya. Demikian juga dalam perilaku keagamaan. Anak mampu memiliki perilaku keagamaan karena menyerap secara terus menerus perilaku keagamaan dari orang-orang terdekatnya, terutama orangtua dan anggota keluarga yang lain. Ditambah dengan daya sugesti dan sikap positif orangtua terhadap perilaku yang telah dilakukan akan memperkuat aktivitas anak dalam berperilaku keagamaan (Otib Satibi, 2009: 8.15).

4. Agama sebagai Aturan

Pemahaman anak terhadap agama menggap bahwa agama merupakan aturan yang harus dilakukan oleh anak yang didasarkan oleh perintah dan penekanan oleh orang tua, guru dan disekitarnya, dengan demikian anak mengenal agama sebatas pemahaman bahwa harus melaksanakan sholat, puasa, dan perberbuatan baik lainnya. Hal ini selaras dengan teori tentang moral oleh Piaget, bahwa anak usia 4-7 tahun menunjukkan moralita heternom, yaitu tahap pertama dari perkembangan moral. Anak berpikir bahwa keadilan dan peraturan adalah properti dunia yang tidak bisa diubah dan dikontrol oleh orang. Anak berpikir bahwa peraturan dibuat oleh orang dewasa dan terdapat pembatasan-pembatasan dalam bertingkah laku.

Pada masa ini anak menilai kebenaran atau kebaikan tingkah laku berdasarkan konsekuensinya, bukan niat dari orang yang melakukan. Anak juaga percaya bahwa aturan tidak bisa diubah dan diturunkan oleh sebuah otoritas yang 
berkuasa. Anak berfikir bahwa mereka tidak berhak membuat peraturan sendiri, melainkan dibuatkan aturan oleh orang dewasa. Orang dewasa perlu memberikan kesempatan pada anak untuk membuat peraturan, agar anak menyadari bahwa peraturan berasal dari kesepakatan dan dapat diubah. (Slavin, 2008:69)

5. Agama sebagai Identitas Agama

Pemahaman anak terhadap agama selain dari konsep pahala-dosa, syurganeraka dan perbuatan ibadah dzhoir, ada juga anak yang mengenal agama sebatas pemahaman bahwa identitas nama agamanya adalah islam. Anak juga mengenal agama sebatas mengenal nama-nama agama saja.

Pemahaman anak terhadap agama sebagai identitas agama yang hanya seperti anak mempunyai nama, hanya sebatas tanda keterangan ucapan saja, tidak masuk pada identitas agama secara sadar pengamalan isi agama tersebut. hal ini terjadi karena ada beberapa kebiasaan percakapan ketika memperkenalkan diri termuat pekenalan agama apa? Atau didalam lagu terselip lirik yang mencantumkam nama agama anak tersebut apa ?. Hal demikanlah yang membuat anak terekam bahwa agama merupakan nama dari bagi identitas dirinya. 


\section{KESIMPULAN}

Pemahaman anak terhadap agama berdasarkan persepsi guru PAUD (RA) terbagi menjadi 4 dimensi, yaitu:

1. Konsep pahala dan dosa, anak memahami konsep pahala dan dosa berdasarkan perbuatan baik yang dilakukannya kepada orang lain, seperti menolong teman akan mendapat pahala , apabila berbuat nakal dengan teman akan mendapat dosa, apabila berbohong, tidak melaksankan sholat akan mendapatkan dosa. Cara guru menanamkan konsep pahala dan dosa ini kepada anak dengan mengenalkan rukun Islam dan rukun Iman melalui bernyanyi dan penjelsan-penjelasan.

2. Konsep syurga dan neraka, sebenarnya kelanjutan dari akibat ketika anak diperknalkan dengan konseppahaladan dosa, karena ujung dari tujuan pahala dan dosa adalah kelak akan bertempat di syurga atau di neraka. Apabila banyak perbuatan baik maka banyak pahala bila banyak pahala maka nanti akan masuk syurga, syurga itu tempat yang enak. Sedangkan neraka dipemahaman anak adalah sebuah tempat yang ada api bernyala-nyala yang sangat panas yang membakar penghuninya. Adapun anak mengenal syurga dan neraka berdasarkan penjelsan dan kebiasaan dari orang disekitarnya, baik orang tua maupun guru.

3. Konsep perbuatan ibadah dzhoir, pemahaman anak terhadap agama hanya sebatas ibadah apa yang nampak (dzohir) dilihatnya dalam sehari-hari baik dirumah, di sekolah dan lingkungannya. Jadi, anak menganggap agama sebuah perbuatan ibadah yang dilakukan seseorang seperti; sholat, membaca al-Qur'an, membaca as-Maul Husna, membaca do'a-do'a. Dengan demikian, anak mengenal agama hanya sebatas meniru atau ikut-ikutan yang dilakukan orang disekitarnya terhadap pelafalan (bacaan) dan gerakan/peragaan tata cara ibadah tersebut seperti sholat dan ibadah lainnya.

4. Agama sebagai aturan, bahwa anak memahami agama merupakan sebagai aturan yang harus dilakukan oleh anak yang didasarkan oleh 
perintah dan penekanan oleh orang tua, guru dan disekitarnya, dengan demikian anak mengenal agama sebatas pemahaman bahwa harus melaksanakan sholat, puasa, dan perberbuatan baik lainnya

5. Agama sebagai identitas agama, pemahaman anak terhadap agama selain dari konsep pahala-dosa, syurga-neraka dan perbuatan ibadah dzhoir, ada juga anak yang mengenal agama sebatas pemahaman bahwa identitas nama agamanya adalah islam. Identitas agama yang hanya sepeti anak mempunyai nama, hanya sebatas tanda keterangan ucapan saja.

\section{Dafatar Pustaka}

Hidayat Satibi, Otib. 2009. Metode Pengembangan Moral dan Nilai-Nilai Agama. Jakarta: Universitas Terbuka

Idi, Abdullah \& Suharto, Toto. (2006). Revitalisasi Pendidikan Islam. Yogyakarta: Tiara Wacana

Mulyasa. 2012. Manajemen PAUD. Remaja Rosdakarya Bandung

Mursid. (2015). Belajar dan Pembelajaran PAUD. Bandung : Remaja Rosdakarya.

Nata, Abuddin. 2011. Ilmu Pendidikan Islam. Jakarta: Kencana

Purwadarminta W.JS. , Kamus Umum Bahasa Indonesia, Jakarta: Balai Pustaka, 1999

Rahman, Hibana S. (2002). Konsep Dasar Pendidikan Anak Usia Dini. Yogyakarta: PGTKI Press

Rahmat, Jalaluddin. 2003. Psikologi Agama. Jakarta: PT. Grafindo Persada

Slavin, Robert E. 2008. Psikologi Pendidikan: Teori dan Praktik. Jakarta: PT. Indeks.

Sugiyono, Metode Penelitian Pendidikan Pendekatan Kuantitatif, Kualitatif dan R\&D, Jakarta: Rineka Cipta, 2013

Syukir, Asmuni. Dasar-Dasar Strategi Dakwah Islam. Surabaya : Al-Ikhlas,t,t 